\title{
Author Correction: Social attraction in Drosophila is regulated by the mushroom body and serotonergic system
}

Yuanjie Sun (1D, Rong Qiu, Xiaonan Li, Yaxin Cheng (1), Shan Gao (D), Fanchen Kong (D, Li Liu \& Yan Zhu (1)

Correction to: Nature Communications https://doi.org/10.1038/s41467-020-19102-3, published online 22 October 2020

The original version of this Article contains an error in the spelling of the name Dr. Hongtao Qin, which is incorrectly given as Dr. Hongtao Qing in the Acknowledgements section. This has now been corrected in both the PDF and HTML versions of the Article.

Published online: 06 November 2020

\begin{abstract}
(c) (i) Open Access This article is licensed under a Creative Commons Attribution 4.0 International License, which permits use, sharing, adaptation, distribution and reproduction in any medium or format, as long as you give appropriate credit to the original author(s) and the source, provide a link to the Creative Commons license, and indicate if changes were made. The images or other third party material in this article are included in the article's Creative Commons license, unless indicated otherwise in a credit line to the material. If material is not included in the article's Creative Commons license and your intended use is not permitted by statutory regulation or exceeds the permitted use, you will need to obtain permission directly from the copyright holder. To view a copy of this license, visit http://creativecommons.org/licenses/by/4.0/.
\end{abstract}

(C) The Author(s) 2020 